\title{
Ekstrak Patikan Kebo (Euphorbia hirta L.) Menurunkan Hitung Eosinofil Bronkus pada Tikus Wistar Model Asma Alergi
}

\section{Patikan Kebo Extract (Euphorbia hirta L.) Decrease Eosinophil Bronchial Count in Allergenic Asthma Model of Wistar Rats}

\author{
Danus Hermawan $^{1 *}$ Kisrini $^{2}$, Diding Heri Prasetyo ${ }^{3}$ \\ ${ }^{1}$ Departemen Biokimia Fakultas Kedokteran Universitas Sebelas Maret \\ ${ }^{2}$ Departemen Farmasi RS Moewardi Surakarta \\ ${ }^{3}$ Departemen Ilmu Penyakit Dalam RS Moewardi Surakarta \\ Kontak sur-el* : dr.danush63@gmail.com
}

\begin{abstract}
ABSTRAK
Paparan alergen pada saluran napas secara berulang memicu terjadinya reaksi asma alergi. Asma alergi diinduksi oleh degranulasi sel mast yang melepaskan mediator proinflamasi seperti histamin, leukotrien, dan prostaglandin yang memicu terjadinya inflamasi bronkus yang ditandai dengan peningkatan eosinofil bronkus. Peningkatan eosinofil bronkus dapat ditekan oleh asam kafeat dan flavonoid. Penelitian ini bertujuan untuk mengetahui pengaruh pemberian ekstrak patikan kebo terhadap hitung eosinofil bronkus pada tikus Wistar model asma alergi. Subyek penelitian berupa 25 ekor tikus Wistar jantan dengan berat badan $\pm 200 \mathrm{~g}$ dan berumur 6 minggu, dibagi dalam 5 kelompok yaitu: Kontrol (K), Asma alergi (A), ekstrak patikan kebo 10 (P1), 15 (P2), 20 mg/tikus/hari (P3). Hitung eosinofil bronkus postes diukur setelah 28 hari perlakuan. Hitung eosinofil bronkus dianalisis dengan SPSS versi 23.0 menggunakan uji One Way ANOVA dan dilanjutkan uji post hoc multiple comparison Tukey. Tingkat kemaknaan digunakan $\mathrm{p}<0,05$. Hitung eosinofil bronkus tikus P1, P2, dan P3 lebih rendah secara bermakna dibanding tikus Asma Alergi $(\mathrm{p}<0.05)$. Patikan kebo mampu menurunkan jumlah eosinofil bronkus pada tikus Wistar model asma alergi.
\end{abstract}

Kata kunci : Patikan kebo, Eosinofil, bronkus, Asma, alergi

\begin{abstract}
Repeated exposure of allergens to the airways triggers allergic asthma reactions. Allergic asthma is induced by mast cell degranulation which releases proinflammatory mediators such as histamine, leukotrienes, and prostaglandins that trigger bronchial inflammation characterized by increased eosinophil bronchial. Increased of eosinophil bronchial can be suppressed by cafeic acid and flavonoids. The aim with the present study was to determine the effect of administering patikan kebo extract to eosinophil bronchial counts in allergic asthma model of Wistar rats. The subjects of the study were 25 male Wistar rats weighing \pm 200 grams and aging 6 weeks, divided into 5 groups: Control (K), allergic asthma (A), patikan kebo extract 10 (P1), 15 (P2), 20 mg/rat/day (P3). The eosinophil bronchial posttest was measured after 28 days of treatment. Eosinophil bronchial counts were analyzed by SPSS version 23.0 using the One Way ANOVA test and continued by the Tukey multiple comparison post hoc test. The level of significance is used $p<0.05$. Bronchial eosinophils of $P 1, P 2$, and $P 3$ rats was significantly lower than those of allergic asthma rats ( $p<0.05)$. Patikan kebo reduced bronchial eosinophyl count in allergic asthma model of Wistar rats.
\end{abstract}

Keywords : Patikan kebo, Bronchial, eosinophil, Allergic, Asthma

\section{PENDAHULUAN}

Alergi adalah suatu keadaan hipersensitivitas yang diinduksi oleh pajanan terhadap suatu antigen (alergen) tertentu yang menimbulkan reaksi imunologik berbahaya pada pajanan berikutnya (Dorland, 2002). Alergi dapat menyerang setiap organ tubuh terutama kulit, saluran pencernaan, dan 
saluran pernafasan (Gould \& Sutton, 2008). Alergi yang terjadi pada saluran pernafasan dapat menimbulkan asma alergi (Galli \& Tsai, 2012). Asma alergi ditandai dengan adanya peningkatan eosinofil bronkus (Rosenberg, Phipps, \& Foster, 2007).

Peningkatan eosinofil bronkus diinduksi oleh inflamasi yang terjadi di bronkus yang disebabkan oleh degranulasi sel mast yang melepaskan mediator-mediator proinflamasi seperti histamin, leukotrien, dan prostaglandin (Carter \& Bradding, 2011). Degranulasi sel mast diaktivasi oleh crosslinking antara $\operatorname{IgE}$ dengan alergen pada permukaan sel mast (Gangwar, Landolina, Arpinati, \& Levi-Schaffer, 2017). Degranulasi sel mast dapat ditekan oleh flavonoid dan asam kafeat (Yoosoo, et al., 2013).

Patikan kebo merupakan tanaman yang banyak ditemukan di kebun, pekarangan, dan di pinggir sawah yang berdasarkan penelitian mengandung asam kafeat dan flavonoid (Asha, Thirunavukkarasu, \& Mohamad, 2015). Kuersetin berfungsi sebagai mast cell stabilizer sehingga dapat mencegah degranulasi sel mast (Weng, et al., 2012). Flavonoid berfungsi sebagai antiinflamasi maupun antihistamin (Toshio \& Ryo, 2013). Asam kafeat yang terkandung pada patikan kebo berfungsi sebagai antihistamin, antiinflamasi, antispasmotik, immunostimulan, dan leukotriene-inhibitor yang dapat menghambat pembentukan leukotrien sehingga dapat mencegah aktivasi dan perekrutan eosinofil menuju tempat inflamasi (Majid Y, Hugh, Akram, Par, \& Peter J, 2001).

\section{METODE}

Subjek penelitian dalam penelitian ini adalah tikus Wistar jantan yang berusia 6 minggu dengan berat rata-rata 200 gram. Tikus tersebut kemudian dibagi menjadi 5 kelompok, yaitu kelompok tikus kontrol (K), kelompok tikus asma alergi (A), kelompok tikus asma alergi diberi perlakuan ekstrak patikan kebo 10 mg/tikus/hari (P1), kelompok tikus asma alergi diberi perlakuan ekstrak patikan kebo 15 mg/tikus/hari (P2), dan kelompok tikus asma alergi diberi perlakuan ekstrak patikan kebo $20 \mathrm{mg} /$ tikus/hari (P3). Setiap kelompok terdapat 6 ekor tikus, sehingga jumlah tikus yang dipergunakan di dalam penelitian ini sebanyak 30 ekor. Ekstraksi patikan kebo menggunakan metode sokletasi dengan menggunakan pelarut etanol $70 \%$.

Setelah adaptasi selama 7 hari, tikus kontrol $(\mathrm{K})$ diberikan diet standar tikus tanpa diberi perlakuan sedangkan tikus A, P1, P2, dan P3 diberikan perlakuan berupa sensitisasi ovalbumin (OVA) selama 28 hari. Setelah perlakuan 28 hari, tikus A tidak diberi intervensi, sedangkan tikus $\mathrm{P} 1, \mathrm{P} 2$, dan $\mathrm{P} 3$ diberikan intervensi berupa ekstrak patikan kebo 10 (P1), 15 (P2), dan 20 mg/tikus/hari (P3).

Hari ke-28 setelah intervensi, semua kelompok tikus diterminasi dengan cara 


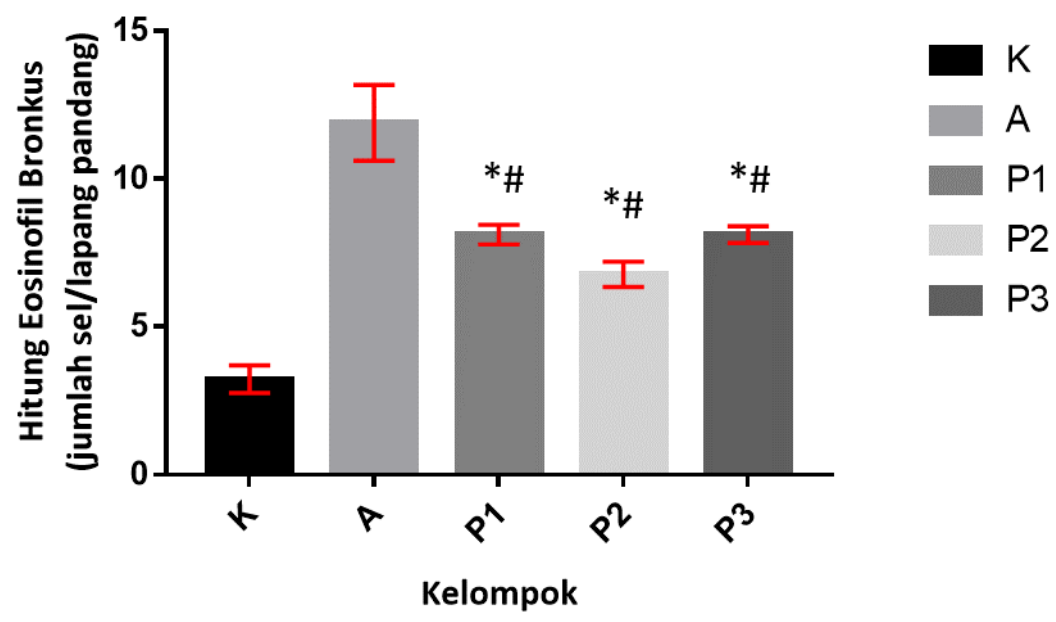

Keterangan :

Sebaran data hitung eosinofil bronkus diuji menggunakan Shapiro-Wilk ( $\mathrm{p} \geq 0,05)$. Uji One Way ANOVA ( $\mathrm{p}>0,05)$. Post hoc test dengan uji Tukey $(p<0.05)$. *berbeda signifikan dengan kelompok Kontrol. \# berbeda signifikan dengan kelompok Asma alergi.

$\mathrm{K}=$ kelompok Kontrol Normal $\mid \mathrm{A}=$ kelompok Asma alergi $\mid \mathrm{P} 1$ : kelompok Asma alergi + ekstrak patikan kebo 10 mg/tikus/hari | P2 : kelompok Asma alergi + ekstrak patikan kebo 15 mg/tikus/hari | P3 : kelompok Asma alergi + ekstrak patikan kebo $20 \mathrm{mg} /$ tikus/hari

$\mathrm{p}<0,05$ dikategorikan nilai yang bermakna

\section{Gambar 1. Hitung Eosinofil Bronkus Tikus}

cervical dislocation dan diambil jaringan bronkus utama didekat percabangan (bifurcatio) sepanjang $1,5 \mathrm{~cm}$, kemudian direndam dalam larutan formalin buffer $10 \%$ selama 10 jam, setelah itu dibuat blok parafin. Selanjutnya dilakukan potongan serial terhadap blok parafin tersebut untuk dibuat slide. Setelah itu dilakukan pewarnaan dengan Hematoksilin Eosin (HE) untuk melihat dan menghitung jumlah eosinofil bronkus, untuk selanjutnya diidentifikasi dengan mikroskop cahaya dengan perbesaran $10 \times 40$.

Hasil penelitian dianalisis menggunakan program analisis statistik SPSS versi 23.0. Data disajikan dalam bentuk mean \pm standard deviation (SD). Data diuji distribusi normalnya menggunakan uji Saphiro-Wilk. Apabila data terdistribusi normal, analisis hitung eosinofil bronkus menggunakan uji
Anova dilanjutkan dengan post hoc multiple comparison Tukey untuk membandingkan perbedaan mean antar kelompok. Jika data tidak memenuhi syarat untuk uji Anova, sebaran data tidak normal $(\mathrm{p}<0,05)$ dan varians data tidak sama meskipun sudah ditransformasi, digunakan uji alternatifnya yaitu uji Kruskal Wallis untuk membandingkan perbedaan mean lebih dari dua kelompok. Pengujian dilanjutkan uji Mann Whitney, untuk membandingkan perbedaan mean antar kelompok.

\section{HASIL DAN PEMBAHASAN}

Hitung eosinofil bronkus masing-masing kelompok disajikan dalam bentuk Mean $\pm S D$ pada gambar 1. Hitung eosinofil bronkus tikus Asma alergi (A) secara signifikan lebih tinggi dibandingkan dengan tikus kontrol (K), dan juga secara signifikan lebih tinggi 
Gambar 1. Hitung Eosinofil Bronkus Tikus

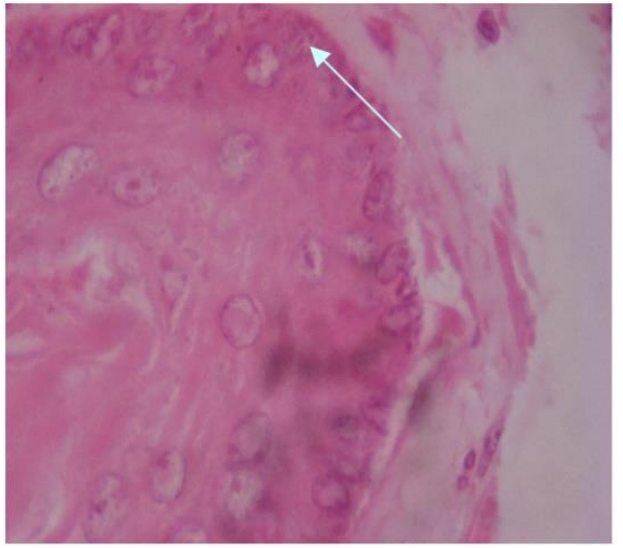

a

Keterangan :

a. Tikus kelompok asma alergi (A)

b. Tikus kelompok asma alergi + patikan kebo $(\mathrm{P} 2)$

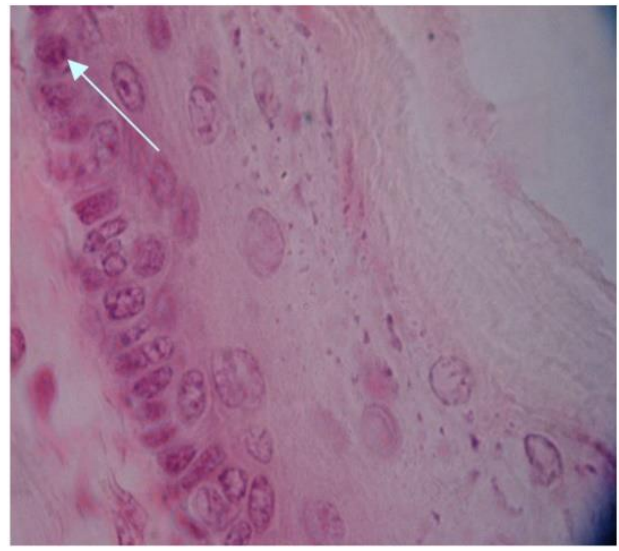

b

Gambar 2. Gambaran bronkus tikus dengan pengecatan Hematoksilin Eosin dalam perbesaran 10 x 40. Eosinofil ditunjukkan dengan anak panah.

dibandingkan dengan tikus asma alergi yang diberi ekstrak patikan kebo berbagai dosis ( $p$ $<0,05)$. Hitung eosinofil bronkus pada tikus asma alergi yang diberi ekstrak patikan kebo secara signifikan lebih rendah dibandingkan dengan tikus asma alergi (A) dan tikus kontrol (K), dan tidak ada perbedaan yang signifikan antara tikus asma alergi yang diberi ekstrak patikan kebo pada dosis yang berbeda (P1, P2, dan P3).

Hitung eosinofil bronkus tikus asma alergi lebih tinggi secara bermakna $(\mathrm{p}<0,05)$ dibandingkan jumlah eosinofil bronkus kelompok kontrol. Hasil ini menunjukkan pemberian Ovalbumin (OVA) dapat meningkatkan jumlah eosinofil bronkus tikus Wistar. Sesuai dengan penelitian (Laprise, et al., 2004) yang menyatakan bahwa paparan OVA dapat menginduksi proses alergi pada hewan percobaan, sehingga mengalami perkembangan hiperresponsifitas saluran nafas dan perekrutan eosinofil ke dalam jaringan bronkus melalui mekanisme bahwa OVA mengaktivasi sel mast dan sel $\mathrm{CD}^{+}$ Th2 pada saluran nafas (Busse \& Lemanske, 2001). Sel mast yang terdegranulasi dan sel $\mathrm{CD}^{+}$Th2 tersebut akan menginduksi produksi mediator-mediator inflamasi seperti histamin, leukotrien dan IL-5 yang dapat menyebabkan eosinofilia. Eosinofilia dipandang sebagai tanda penyakit alergi (Rosenberg, Phipps, \& Foster, 2007).

Jumlah eosinofil bronkus tikus P1, P2, dan P3 menunjukkan angka yang lebih rendah dibandingkan tikus asma alergi. Hasil ini menunjukkan secara bermakna ekstrak patikan kebo mampu menekan proses asma alergi ditandai dengan penurunan jumlah eosinofil bronkus. Patikan kebo mempunyai kandungan kimia flavonoid dan asam kafeat 
yang memiliki efek farmakologis sebagai antagonis kalsium, antileukotrien, antihistamin, prostaglandin-synthesis inhibitor dan antiinflamasi (Asha, Thirunavukkarasu, \& Mohamad, 2015). Menurut Toshio \& Ryo (2013) flavonoid dapat menghambat enzim lipooksigenase dan berperan dalam menghambat degranulasi sel mast melalui mekanisme penghambatan pelepasan $\mathrm{Ca}$ intraseluler (Yoosoo, et al., 2013). Dengan dihambatnya enzim lipooksigenase dan degranulasi sel mast maka mediator yang menstimulasi perekrutan eosinofil ke jaringan, seperti histamin, leukotrin, dan prostaglandin, tidak terbentuk. Menurut Weng et al. (2012) kuersetin menghambat degranulasi sel mast sehingga pelepasan mediator inflamasi seperti histamin, leukotrien, dan prostaglandin terhambat menyebabkan aktivasi dan perekrutan eosinofil bronkus berkurang. Kuersetin dan asam kafeat dapat menghambat leukotrin, histamin, dan Prostaglandin D2 yang dilepaskan oleh sel mast sehingga menurunkan aktivasi dan perekrutan eosinofil menuju bronkus serta inflamasi saluran nafas (Majid Y, Hugh, Akram, Par, \& Peter J, 2001).

Pemberian ekstrak patikan kebo dosis 10, 15 dan $20 \mathrm{mg} /$ tikus/hari tidak menunjukkan perbedaan yang bermakna dalam menurunkan jumlah eosinofil bronkus. Hasil ini menunjukkan ekstrak patikan kebo dosis 10 mg/tikus/hari memiliki kemampuan yang tidak jauh berbeda dengan ekstrak patikan kebo dosis 15 dan $20 \mathrm{mg} /$ tikus/hari dalam menurunkan jumlah eosinofil bronkus tikus Wistar model asma alergi, sehingga untuk penelitian lebih lanjut bisa digunakan patikan kebo dosis 10 mg/tikus/hari.

\section{KESIMPULAN}

Patikan kebo mampu menurunkan jumlah eosinofil bronkus pada tikus Wistar model asma alergi.

\section{UCAPAN TERIMA KASIH}

Penulis mengucapkan terima kasih kepada Fakultas Kedokteran Universitas Sebelas Maret yang telah memberikan fasilitas untuk pelaksanaan penelitian ini dan Direktorat Jenderal Pendidikan Tinggi (DIKTI) untuk pendanaan terhadap penelitian ini.

\section{DAFTAR PUSTAKA}

Asha, S., Thirunavukkarasu, P., \& Mohamad, S. (2015). Phytochemical screening of Euphorbia hirta linn leaf extracts. World $J$ Pharm Sci, 3(6): 1104-1112.

Busse, W., \& Lemanske, R. (2001). Asthma. N. Engl. J. Med. , 344: 350-362.

Carter, R., \& Bradding, P. (2011). The role of mast cells in the structural alterations of the airways as a potential mechanism in the pathogenesis of severe asthma. Curr Pharm Des, 17(7):685-98.

Dorland, W. N. (2002). Kamus Kedokteran Dorland. Jakarta: EGC.

Galli, S., \& Tsai, M. (2012). IgE and mast cells in allergic disease. Nat Med, 18(5):693-704.

Gangwar, R., Landolina, N., Arpinati, L., \& Levi-Schaffer, F. (2017). Mast cell and eosinophil surface receptors as targets for anti-allergic therapy. Pharmacol Ther, 170:37-63.

Gould, H., \& Sutton, B. (2008). IgE in allergy and asthma today. at Rev Immunol, 8:20517. 
Laprise, C., Sladek, R., Ponton, A., Bernier, M., Hudson, T., \& Laviolette, M. (2004). Functional classes of bronchial mucosa genes that are differentially expressed in asthma . BMC Genomics, 5: 21.

Majid Y, M., Hugh, S., Akram, J., Par, S., \& Peter J, O. (2001). Caffeic Acid, Chlorogenic Acid, And Dihydrocaffeic Acid Metabolism: Glutathione Conjugate Formation. DMD , 29:1432-1439.

Rosenberg, H., Phipps, S., \& Foster, P. ( 2007). Eosinophil trafficking in allergy and asthma. $J$ Allergy Clin Immunol., 119:1303-10.

Toshio, T., \& Ryo, T. (2013). Flavonoids and Asthma, Nutrients. Nutrients, 5(6): 21282143.
Weng, Z., Zhang, B., Asadi, S., Sismanopoulos, N., A, B., Fu, X., . . . Theoharides, T. (2012). Quercetin is more effective than cromolyn in blocking human mast cell cytokine release and inhibits contact dermatitis and photosensitivity in humans. PLoS, 7(3): e33805.

Yoosoo, Y., Jung-Mi, O., Paul, H., Jae Yoon, S., Byoungjae, K., Jonghyeok, S., . . DaeHyuk, K. (2013). Polyphenols differentially inhibit degranulation of distinct subsets of vesicles in mast cells by specific intercation with granule-typedependent SNARE complexes. Biochem J, 450(3): 537-546. 